\title{
An Assessment of Customer Retention with Self-Service Technologies: A Model Development
}

\author{
Ali Alsiehemy \\ Middlesex University, Business School, London \\ E-mail: lealsiehemy@hotmail.com
}

Received: September 25, 2017 Accepted: October 2, $2017 \quad$ Published: April 19, 2019

doi:10.5296/bms.v10i1.14686ＵRL: https://doi.org/10.5296/bms.v10i1.14686

\begin{abstract}
This paper reviews the literature relating to self service technologies (SST) with the purpose of building an accurate and clear picture of the most important aspects associated with this technology. It also reviews the literature on customer retention using SST. By examining studies of SST, it can be seen that many have examined SST from different perspectives (customers vs. organisations) in different contexts (banks, libraries, airlines, hotels and retailers) and in different cultures and countries (developed, developing). Thus, this chapter, after providing an overview of SST, discusses the topic from the organisational perspective by focusing on areas concerned with the contribution of SST to organisational performance (e.g. profitability, productivity, marketing relationship, service quality and cutting costs). A closer look at these studies clearly reveals the breadth and diversity of studies investigating SST from the customers' perspective, whereby it is noteworthy that the majority have focused on examining the usage patterns of SST (e.g. behavioural intention, usage behaviour, adoption, future intention). Finally, this chapter examines the use of SST in banks to retain customers as well as the profitability of customer retention.
\end{abstract}

Keywords: Self Service Technology (SST), Customer Retention, Internet Banking, Mobile Banking. 


\section{Introduction}

The world has been significantly changed by the internet and its follow-up products. The most influential impact has been on the banking sector, which demands fast service and a high level of customer satisfaction. The adoption of internet technology triggered the development of the banking sector, with the most eye-catching feature being a customer focus regarding their relationship with banks. The internet promotes the concept of retention, which also underlines the value of an old and loyal customer. With the help of internet technology, banks can provide better service to their customers and offer new features which speed up the process, enabling them to gain a competitive advantage in the market without the need for physical contact with the customer. Nowadays, people use banking services without much effort through the internet and communication technology. Self-service technology also helps the customer to use customized banking services. From a marketing perspective, SST is not merely another marketing tool, but it can also be a strategic tool to help banks increase consumer recruitment, retention and development (the buying of additional products and services).

In the service provided using SST, retaining existing customers should be more cost-effective than acquiring a new customer (Blut, Wang and Schoefer, 2016; Van Akkeren, and Cavaye, 1999). The banking companies today have entered a race of acquisition for new customers and may have forgotten their old, loyal customers. Banks should focus on the long-term relationship with the customer rather than a one-time service relationship. Customer retention is very important for all service sector firms and will receive increasing attention in the next few years (Appiah-Adu, 1999; Fernandes and Pedroso, 2017). Internet technology improves efficiency and lowers the cost of service, whereby the best use of the internet has been shown in developed countries. Many banks have websites and provide 24-hour assistance to their customers. Now this wave has moved to Saudi Arabia and Middle Eastern countries, whose markets have full potential. With the growth of the internet and communication technology, customer retention has been a problem and this is partially due to the lack of literature focusing on this perspective. Therefore, this study aims to explore the studies and theoretical models built around technology adoption, customer satisfaction and customer retention.

\section{Literature Review}

\subsection{Overview of Self-Service Technology (SST)}

The results of customers' communications in traditional meetings with companies largely rely on how much the organisation's workers can successfully create and distribute the needed services (Al-Hawari et al., 2009). The output and success of traditional encounters are heavily reliant on human aspects (customers and employees), making it difficult to preserve a dependable level of performance (Bitner et al., 2000; Dean, 2008).

Given the strength of competition in many service industries, including banking, customer sensitivity is increasing because of the issues related to cost, time and suitability of service as well as the need to keep up with technical progress. Many organisations have invested in 
technology to overcome the limitations of human encounters (Al-Hawari et al., 2009; Lin and Hsieh. 2011; Orel and Kara, 2014; Williams et al., 2014), aiming to achieve a high service value and quality by using channels which are innovative, productive and cost-effective for both customers and organisations (Chiu et al., 2010; Zhu and Chen, 2012; Hilton et al., 2013; Lee and Yang, 2013). One of these innovations is self-service technology (SST), which offers a way of providing customers with a varied range of facilities while replacing the role of a human encounter (Curran and Meuter, 2005; Kokkinou and Cranage, 2013; Meuter et al., 2005; Salomann et al., 2005; Weijters et al., 2007).

SST is defined as "technological interfaces that enable customers to produce a service that is independent of direct service employee involvement” (Meuter et al., 2005, p.50). It converts service processes from "low tech, high touch to high tech, low touch" (Bitner et al., 2000, p.138), whereby the customer can take more responsibility in producing services (Meuter et al., 2005). This highlights the significant role of customers as creators and makers of added value rather than as just recipients, and ultimately improves their role in the firm's efficiency and cost-effectiveness (Hilton et al., 2013; Lee and Yang, 2013; Liljander et al., 2006; Lin and Hsieh, 2011; Salomann et al., 2005).

According to Bitner et al. (2002) and Meuter et al. (2005), four common kinds of technology services (SSTs) have been widely applied in the service context: telephone/interactive voice response (IVR) (e.g. telebanking); internet-based interfaces (e.g. online shopping); interactive kiosks (e.g. automated teller machine (ATM)); and video/CD.

If customers are unwilling to use SST, corporations must continue to deliver services via human encounters, with their associated operational and labour costs (Chiu et al., 2010; Hilton et al., 2013; Hung et al., 2012). Also, the absence of human communication could generate problems pertaining to failure before, during or after delivery of the service when using SST (Curran et al., 2003). Another problem relating to SST is that substituting it for human interaction could delay the creation of relationship bonds and so negatively influence customer loyalty (Proença and Silva, 2007; Salomann et al., 2005).

The role of SST in improving company performance in areas such as success, efficiency, advertising relationships, service quality, and cost reductions has already been emphasised in previous studies (Campbell and Frei, 2010; Hung et al., 2012).

\subsection{An Individual's Characteristics}

An individual customer's characteristics influence their willingness to adopt or reject SST (Chiu et al., 2010; Dabholkar and Bagozzi, 2002; Gelderman et al., 2011). Ding et al. (2007) argued that perceived behavioural control is of interest for SST users and plays a vital role in motivating them to use SST. Perceived behavioural control was found to have a positive influence on customer satisfaction with SST, and ultimately on the customers' willingness to use SST in the future (Chen et al., 2009).

Other important personality traits are the technology readiness dimensions of optimism, 
innovativeness, discomfort and insecurity. These have been argued as being critical determinants in encouraging or discouraging customers' use of SST innovations in their daily lives (Chiu et al., 2010; Liljander et al., 2006; Lin and Hsieh, 2011; Meuter et al., 2005). Meuter et al. (2005), for instance, found that customer judgements of SST were determined by three aspects of customer readiness, namely role clarity, intrinsic and extrinsic motivation, and customer ability.

\subsection{Demographic Factors}

The effect of demographic variables has received much attention from scholars, which confirm that variations in customers' responses to and impressions of SST could be credited to the variety contained within the customers' demography (Dabholkar et al., 2003; Dean, 2008; Simon and Usunier, 2007). Dabholkar et al. (2003) stated that there were critical contrasts in usage pattern examples of SST attributed to demographic contrasts (age, gender and education). In fact, preferences to use ATMs reached the highest levels among more youthful customers; furthermore, younger men seem to prefer using web-based shopping as opposed to interactive voice shopping (Dabholkar et al., 2003). However, according to Lee et al. (2010), there are no significant variations regarding customers' intentions that are due to demographic differences.

\subsection{Customer Attitudes}

Customer attitudes toward SST or service providers have usually been delineated as key forecasters of customer intention and usage of SST. Both perceived ease of use and perceived usefulness were key antecedents of customers' attitudes, leading in turn to a higher likelihood of customers accepting the technological interfaces

\subsection{Motives for using SST}

Researchers have mentioned several motives that could accelerate customer inclinations to use SST. Noticeably, cost saving has been widely recognised as a positive rationale clarifying why customers favour interacting with SST rather than a human encounter (Ding et al., 2007). Self-service technology channels also allow customers to access information and services without time and place restrictions; thus, time saving has been identified as a positive driver of customers' attitude towards and usage of SST (Ding et al., 2007; Meuter et al., 2005). The speed of service delivery, hedonic utilities and perceived privacy comprise the key benefits expected by customers when using SST. In their qualitative study, Hilton et al. (2013) implied that customers are more enthusiastic when valuing SST if they perceive it as more suitable, quicker, less expensive, and able to provide them with more unique offers than traditional channels.

In some cases, customers' decisions to accept or reject SST were found to be predicted by other external factors, such as the impact of the physical environment (e.g. situational factors such as waiting time, perceived crowdedness, urgent needs, accessibility, facilities) or aspects related to the social environment (e.g. social influences, reference group, family, word of 
mouth, subjective norms) (Chiu et al., 2010; Dabholkar and Bagozzi, 2002; Dabholkar et al., 2003).

Several studies have paid particular attention to issues that are concerned with trust, perceived risk, privacy and security, assurances, integrity, competence, credibility, confidently and reliability (Curran and Meuter, 2005; Flavián et al., 2006). These constructs have been widely regarded as crucial determinants of customers' intentions and the adoption of SST, particularly in the banking sector (e.g., Flavián et al., 2006). The main focus of the current study is SST applications in Saudi Arabian banking (internet banking and mobile banking). Therefore, it is necessary to review the main studies that examine SST in banking to give a better understanding of the most fundamental factors predicting customer intention and usage of SST banking channels. The following sections will discuss the main literature on SST banking channels by reviewing the internet and mobile banking literature.

\section{Customer Retention}

The retention of customers is a conceptualisation of a customer loyalty dimension (Zeithaml et al., 1996). Its concern is with the return of customers, this is closely linked to behaviours in repeat purchases and loyalty to a brand (Jacoby et al., 1978). Conversely, customer retention can be defined as the likelihood of customers to remain with their current supplier (Ranaweera and Prabhu, 2003).

\subsection{Customer Retention Impact in regard to Profitability}

Research has shown that companies in competitive markets have realised that one of their most valuable assets is within their existing base of customers (Schemer et al. 2015; Verhoef, 2003). Other research has shown that relationships with customers in the long term are preferable since they have the potential for greater profit (Buchanan and Gillies, 1990; Reichheld and Sasser, 1990; Fornell, 1992). One of the observations is that attracting a new customer comes at a cost which is approximately 6 times greater than keeping an existing customer. An increase in customer retention can bring extra sales, lower costs, acceptances of price rises, and recommendations via word of mouth. Aside from the negligible evidence available in regard to negative lifetime-profitability relationships, it is seen that most lifetime relationship outcomes are positive along the diagonal line, as shown in Figure 1. 
High

Profit

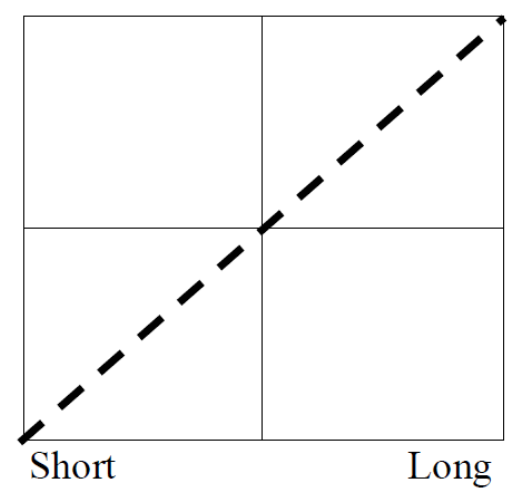

Low

\section{Lifetime}

Figure 1. Lifetime-profitability association

Source: Reinartz and Kumar (2000)

\subsection{Sustaining Customer Retention}

The majority of organizations have focussed their efforts on the creation, development, and maintenance of various types of relationship with different partners in different markets. Some of these long-term relationships exist between representative and manufacturer (McQuiston, 2001) and distributor and manufacturer (Ryu and Eyuboglu, 2007). Retailers have sought a committed and long-term relationship with their suppliers (Fynes and Voss, 2002), whilst companies have sought a lasting relationship with their employees (Crosby, 2002). Service providers have focussed their efforts on creating and maintaining relationships with the customer (Harrison-Walker and Coppett, 2003). Yet, most service delivery systems have not been able to keep potential customers (Anderson, and Narus 1990). Egan (2001) states that companies need to identify and establish, improve and maintain, and be willing to end a relationship with a customer or with another stakeholder.

\section{Internet Banking}

\subsection{The Effect of Internet Banking Characteristics}

The characteristics of internet banking (for example, convenience, trialability, complexity, and compatibility) are increasingly seen as key to explaining the significant variance in customer intention and the accepted use of internet banking (Black et al., 2001; Gerrard and Cunningham, 2003; Shih and Fang, 2004; Gan et al., 2006). Gerrard and Cunningham (2003) state that there are significant differences between those who do, and those who do not, adopt internet banking regarding their perception of aspects associated with complexity and convenience. Both aspects of innovation—relative advantage and complexity-were tested by Shih and Fang (2004) and were found to be strong predictors of customer attitudes related 
to internet banking which, in turn, considerably determined customer intention. Gan et al. (2006) found that customers' decisions to use internet banking instead of traditional channels were significantly predicted by reliability, assurance and responsiveness.

\section{Mobile Banking}

In accordance with Zhou et al. (2010), customers' adoption of mobile banking was statistically correlated with performance expectancy, facilitating conditions, social influences and task technology. Similar findings were reached by Chiu et al. (2010), who demonstrated that performance expectancy, facilitating conditions, social influences and effort expectancy were all significant determinants of customers' inclination to use mobile banking. Indeed, adopters are more likely to be different in their awareness of these predictors in comparison to non-adopters (Chiu et al., 2010). Yu (2012) also confirmed a strong and positive correlation between customers' intentions and actual usage of mobile banking. In addition, social influences, performance expectancy and perceived credibility have been acknowledged by Yu (2012) as being positive indicators of customers' intention to use mobile banking. However, effort expectancy, as stated by Yu (2012), does not present any concern for customers when formulating their intention to adopt mobile banking. Zhou et al. (2010) observed that the role of effort expectancy in behavioural intention was restricted by the indirect influence of performance expectancy. Püschel et al. (2010) debated that even though perceived behavioural control was strongly affected by both self-efficacy and facilitating conditions, perceived behavioural control does not have a statistical association with customer willingness to adopt mobile banking.

\subsection{Factors Leading to Rejection}

In a comparison study examining non-users of mobile banking in two countries (Finland and Portugal), Laukkanen and Cruz (2009) found that non-users of mobile banking are more likely to reject it if they perceive it as less compatible with other technologies or their habitual behaviour. Laukkanen and Cruz (2009) illustrated that customer resistance to adopting mobile banking is more likely to increase if customers perceive it to be riskier, less advantageous, and not compatible with their image. Equally, ignorance of the existence, concept and benefits of mobile banking represent the foremost obstacles mitigating customer acceptance of mobile banking in China (Laforet and Li, 2005). In Brazil, Cruz et al. (2010) asserted that customers' perceptions regarding aspects like perceived risk, cost perception, utility and difficulty were key barriers hindering the use of mobile banking. Nonetheless, Cruz et al. (2010) observed that the problems with a lack of observability, a lack of information, and unsuitable devices garnered less attention from those who did not use mobile banking.

\section{Model Development}

This paper has shown the relevant literature in regard to internet service retention. Additionally, the researcher has discussed the requirement for identifying additional factors which may have importance in determining SST service retention (mobile banking and 
internet banking).

The literature review identifies that, compared to the theory of planned behaviour (TPB) and the theory of reason action (TRA), the technology acceptance model (TAM) is strong and focusses clearly on the use of internet services. Mathieson (1991) states that TAM is simpler to practically apply, meaning TAM has an experimental advantage over other theoretical models. In regard to these discoveries, the researcher considers that a TAM-based model is better to use than the TRA or TPB when examining how online banking information systems are accepted. Additionally, the literature review shows that the empirical study focus has been on how commercial technologies are accepted, since these are simple and individual technologies. The literature review shows that the TRA, TPB and TAM can be used with a variety of technologies, for example online business and shopping. On the other hand, adopting a TAM model is not enough to measure the retention/continues satisfaction usage, thus the researcher has adopted the ECM model, which can clearly measure these.

The researcher's proposed research model, shown in Figure 3.7, extends TAM/ECM in regard to an SST service system based on previous research into the acceptance and retention of technology. The model proposes that SST service retention is determined by both perceived usefulness (PU) and perceived ease of use (PEOU), drawing from the findings of other researchers (Davis 1989; Venkatesh and Davis, 2000) and ECM model confirmation (Bhattacherjee, 2001).

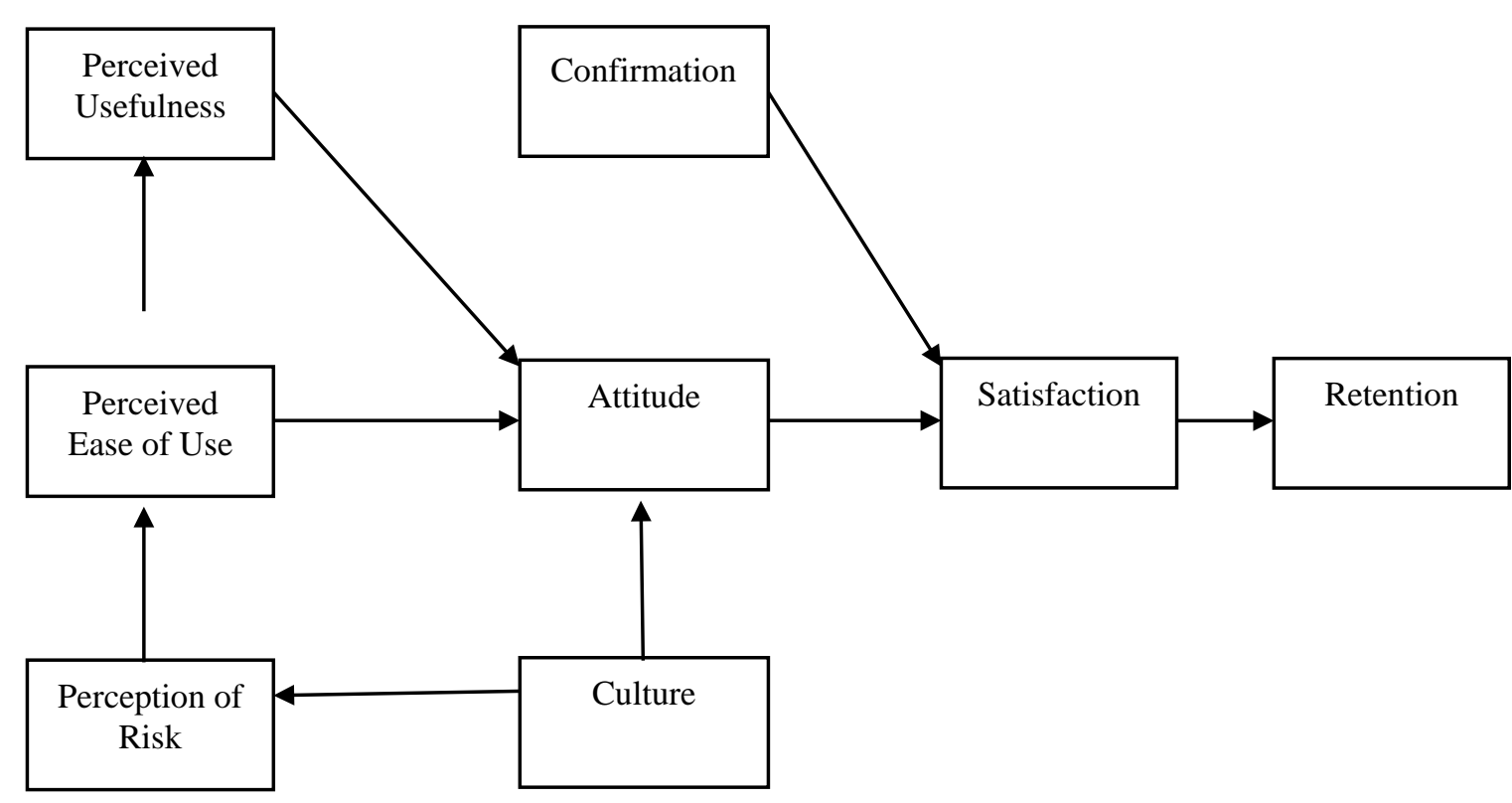

Figure 2. Proposed research model

Definition of Key Terms

The following terms are defined in the context of this research construct. 
Table 1. Key term definitions

\begin{tabular}{|c|l|}
\hline Construct & \multicolumn{1}{c|}{ Definition } \\
\hline Retention & $\begin{array}{l}\text { Repeated patronage, which is closely related to repeat } \\
\text { purchasing behaviour and brand loyalty. }\end{array}$ \\
\hline Perceived usefulness & $\begin{array}{l}\text { The extent to which a person believes that using the system will } \\
\text { enhance his/her job performance. }\end{array}$ \\
\hline Perceived ease of use & $\begin{array}{l}\text { The extent to which a person believes that using the system will } \\
\text { be free of effort. }\end{array}$ \\
\hline Perceived risk & $\begin{array}{l}\text { The uncertainty which primarily relates to potential } \\
\text { technological sources of errors and security gaps. }\end{array}$ \\
\hline Culture & $\begin{array}{l}\text { Mental programming that differentiates the affiliations of one } \\
\text { group of people from another. }\end{array}$ \\
\hline Confirmation & $\begin{array}{l}\text { Users' perception of the congruence between } \\
\text { expectation of online banking division use and its actual } \\
\text { performance. }\end{array}$ \\
\hline Attitude & $\begin{array}{l}\text { The degree to which a person has a favourable or unfavourable } \\
\text { evaluation or appraisal of the behaviour in question. }\end{array}$ \\
\hline Satisfaction & $\begin{array}{l}\text { Overall consumer feelings about a product/ service after they } \\
\text { buy it. }\end{array}$ \\
\hline &
\end{tabular}

\section{References}

Al-Hawari, M., Ward, T., \& Newby, L. (2009). The relationship between service quality and retention within the automated and traditional contexts of retail banking. Journal of Service Management, 20(4), 455-472. https://doi.org/10.1108/09564230910978539

Anderson, J. C., \& Narus, J. A. (1990). A model of distributor firm and manufacturer firm working partnerships. Journal of Marketing, 42-58. http://www.jstor.org/stable/1252172

Appiah-Adu, K. (1999). Marketing effectiveness and customer retention in the service sector. Service Industries Journal, 19(3), 26-41. http://dx.doi.org/10.1080/02642069900000028

Berger, S. C., \& Martin, S.F. (2007). Explaining the adoption of value metrics in retail banks' customer management. In International Workshop on Enterprise Applications and Services in the Finance Industry (pp. 151-164). Springer, Berlin, Heidelberg. https://doi.org/10.1007/978-3-540-78550-7_10

Bhattacherjee, A. (2001). Understanding information systems continuance: an expectation-confirmation model. MIS Quarterly, 351-370. https://doi.org/10.2307/3250921

Bitner, M. J., Brown, S. W., \& Meuter, M.L. (2000). Technology infusion in service 
encounters. Journal of the Academy of Marketing Science, 28(1), 138-149. https://doi.org/10.1177/0092070300281013

Bitner, M. J., Ostrom, A. L., \& Meuter, M. L. (2002). Implementing successful self-service technologies. The Academy of Management Executive, 16(4), 96-108. doi: 10.5465/AME.2002.8951333

Black, J. N., Lockett, A., Winklhofer, H., \& Ennew, C. (2001). The adoption of Internet financial services: a qualitative study. International Journal of Retail \& Distribution Management, 29(8), 390-398. https://doi.org/10.1108/09590550110397033

Blut, M., Wang, C., \& Schoefer, K. (2016). Factors influencing the acceptance of self-service technologies: A meta-analysis. Journal of Service Research, 19(4), 396-416. https://doi.org/10.1177/1094670516662352

Buchanan, R. W., \& Gillies, C. S. (1990). Value managed relationships: the key to customer retention and profitability. European Management Journal, 8(4), 523-526. https://doi.org/10.1016/0263-2373(90)90115-M

Campbell, D., \& Frei, F. (2010). Cost structure, customer profitability, and retention implications of self-service distribution channels: Evidence from customer behavior in an online banking channel. Management Science, 56(1), 4-24. https://doi.org/10.1287/mnsc.1090.1066

Chen, S. C., Chen, H. H., \& Chen, M. F. (2009). Determinants of satisfaction and continuance intention towards self-service technologies. Industrial Management \& Data Systems, 109(9), 1248-1263. https://doi.org/10.1108/02635570911002306

Chiu, Y. H., Fang, S. C., \& Tseng, C. C. (2010). Early versus potential adopters: Exploring the antecedents of use intention in the context of retail service innovations. International Journal of Retail \& Distribution Management, 38(6), 443-459. https://doi.org/10.1108/09590551011045357

Crosby, L. A. (2002). Exploding some myths about customer relationship management. Managing Service Quality: An International Journal, 12(5), 271-277. https://doi.org/10.1108/09604520210442056

Cruz, P., Barretto Filgueiras Neto, L., Muñoz-Gallego, P., \& Laukkanen, T. (2010). Mobile banking rollout in emerging markets: Evidence from Brazil. International Journal of Bank Marketing, 28(5), 342-371. https://doi.org/10.1108/02652321011064881

Curran, J. M., \& Meuter, M. L. (2005). Self-service technology adoption: comparing three technologies. Journal of Services Marketing, 19(2), 103-113. https://doi.org/10.1108/08876040510591411

Dabholkar, P. A., \& Bagozzi, R. P. (2002). An attitudinal model of technology-based self-service: moderating effects of consumer traits and situational factors. Journal of the 
Academy of Marketing Science, 30(3), 184-201. Retrieved from http://journals.sagepub.com/doi/abs/10.1177/0092070302303001\#

Dabholkar, P. A., Michelle Bobbitt, L., \& Lee, E. J. (2003). Understanding consumer motivation and behavior related to self-scanning in retailing: Implications for strategy and research on technology-based self-service. International Journal of Service Industry Management, 14(1), 59-95. https://doi.org/10.1108/09564230310465994

Davis, F. D. (1989). Perceived usefulness, perceived ease of use, and user acceptance of information technology. MIS Quarterly, 319-340. http://www.jstor.org/stable/249008

Dean, D. H. (2008). Shopper age and the use of self-service technologies. Managing Service Quality: An International Journal, 18(3), 225-238. https://doi.org/10.1108/09604520810871856

Ding, X., Verma, R., \& Iqbal, Z. (2007). Self-service technology and online financial service choice. International Journal of Service Industry Management, 18(3), 246-268. https://doi.org/10.1108/09564230710751479

Egan, J. (2001). Throwing the baby out with the bathwater? Marketing Intelligence \& Planning, 19(6), 375-384. https://doi.org/10.1108/02634500110405388

Fernandes, T., \& Pedroso, R. (2017). The effect of self-checkout quality on customer satisfaction and repatronage in a retail context. Service Business, 11(1), 69-92. https://doi.org/10.1007/s11628-016-0302-9

Flavián, C., Guinalíu, M., \& Gurrea, R. (2006). The role played by perceived usability, satisfaction and consumer trust on website loyalty. Information \& Management, 43(1), 1-14. https://doi.org/10.1016/j.im.2005.01.002

Fornell, C. (1992). A national customer satisfaction barometer: The Swedish experience. Journal of Marketing, 6-21. Retrieved from http://www.jstor.org/stable/1252129

Fynes, B., \& Voss, C. (2002). The moderating effect of buyer-supplier relationships on quality practices and performance. International Journal of Operations \& Production Management, 22(6), 589-613. https://doi.org/10.1108/01443570210427640

Gan, C., Clemes, M., Limsombunchai, V., \& Weng, A. (2006). A logit analysis of electronic banking in New Zealand. International Journal of Bank Marketing, 24(6), 360-383. https://doi.org/10.1108/02652320610701717

Gelderman, C. J., Paul, W. T., \& van Diemen, R. (2011). Choosing self-service technologies or interpersonal services-The impact of situational factors and technology-related attitudes. Journal of Retailing and Consumer Services, 18(5), 414-421. https://doi.org/10.1016/j.jretconser.2011.06.003

Gerrard, P., \& Cunningham, J. B. (2003). The diffusion of internet banking among Singapore consumers. International Journal of Bank Marketing, 21(1), 16-28. 
https://doi.org/10.1108/02652320310457776

Harrison-Walker, L. J., \& Coppett, J. I. (2003). Building bridges: The company-customer relationship. Journal of Business to Business Marketing, 10(4), 49-72. http://dx.doi.org/10.1300/J033v10n04_03

Hilton, T., Hughes, T., Little, E., \& Marandi, E. (2013). Adopting self-service technology to do more with less. Journal of Services Marketing, 27(1), 3-12. http://www.emeraldinsight.com/doi/abs/10.1108/08876041311296338

Hung, C. S., Yen, D. C., \& Ou, C. S. (2012). An empirical study of the relationship between a self-service technology investment and firm financial performance. Journal of Engineering and Technology Management, 29(1), 62-70. https://doi.org/10.1016/j.jengtecman.2011.09.006

Jacoby, J., Chestnut, R. W., \& Fisher, W. A. (1978). A behavioral process approach to information acquisition in nondurable purchasing. Journal of Marketing Research, 532-544. Retrieved from http://www.jstor.org/stable/3150623

Kokkinou, A., \& Cranage, D. A. (2013). Using self-service technology to reduce customer waiting times. International Journal of Hospitality Management, 33, 435-445. https://doi.org/10.1016/j.ijhm.2012.11.003

Laforet, S., \& Li, X. (2005). Consumers' attitudes towards online and mobile banking in China. International Journal of Bank Marketing, 23(5), pp.362-380. https://doi.org/10.1108/02652320510629250

Laukkanen, T., \& Cruz, P. (2009). Comparing consumer resistance to mobile banking in Finland and Portugal. In International Conference on E-Business and Telecommunications (pp. 89-98). Springer Berlin Heidelberg. https://doi.org/10.1007/978-3-642-05197-5_6

Lee, H. J., \& Yang, K. (2013). Interpersonal service quality, self-service technology (SST) service quality, and retail patronage. Journal of Retailing and Consumer Services, 20(1), 51-57. https://doi.org/10.1016/j.jretconser.2012.10.005

Liljander, V., Gillberg, F., Gummerus, J., \& Van Riel, A. (2006). Technology readiness and the evaluation and adoption of self-service technologies. Journal of Retailing and Consumer Services, 13(3), 177-191. https://doi.org/10.1016/j.jretconser.2005.08.004

Lin, J. S. C., \& Hsieh, P. L. (2011). Assessing the self-service technology encounters: development and validation of SSTQUAL scale. Journal of Retailing, 87(2), 194-206. https://doi.org/10.1016/j.jretai.2011.02.006

Mathieson, K. (1991). Predicting user intentions: comparing the technology acceptance model with the theory of planned behavior. Information Systems Research, 2(3), 173-191. https://doi.org/10.1287/isre.2.3.173

McQuiston, D. H. (2001). A conceptual model for building and maintaining relationships between manufacturers' representatives and their principals. Industrial Marketing 
Management, 30(2), 165-181. https://doi.org/10.1108/0960039610116521

Meuter, M. L., Bitner, M. J., Ostrom, A. L., \& Brown, S. W. (2005). Choosing among alternative service delivery modes: An investigation of customer trial of self-service technologies. Journal of Marketing, 69(2), 61-83. https://doi.org/10.1509/jmkg.69.2.61.60759

Orel, F. D., \& Kara, A. (2014). Supermarket self-checkout service quality, customer satisfaction, and loyalty: Empirical evidence from an emerging market. Journal of Retailing and Consumer Services, 21(2), 118-129. https://doi.org/10.1016/j.jretconser.2013.07.002

Proença, J. F., \& Silva, M. (2007). Banking relationships and internet banking. International Journal on www/Internet, 5(2), 181-192. Retrieved from https://www.researchgate.net/profile/Joao_Proenca/publication/242606809_BANKING_REL ATIONSHIPS_AND_INTERNET_BANKING/links/00b495375419359554000000.pdf

Püschel, J., Afonso Mazzon, J., Mauro C., \& Hernandez, J. (2010). Mobile banking: Proposition of an integrated adoption intention framework. International Journal of Bank Marketing, 28(5), 389-409. https://doi.org/10.1108/02652321011064908

Ranaweera, C., \& Prabhu, J. (2003). The influence of satisfaction, trust and switching barriers on customer retention in a continuous purchasing setting. International Journal of Service Industry Management, 14(4), 374-395. https://doi.org/10.1108/09564230310489231

Reichheld, F. F., \& Sasser Jr, W.E. (1989). Zero defections: Quality comes to services. Harvard Business Review, 68(5), 105-111. https://doi.org/https://hbr.org/1990/09/zero-defections-quality-comes-to-services

Reinartz, W. J., \& Kumar, V. (2000). On the profitability of long-life customers in a noncontractual setting: An empirical investigation and implications for marketing. Journal of Marketing, 64(4), 17-35. https://doi.org/https://doi.org/10.1509/jmkg.64.4.17.18077

Ryu, S., \& Eyuboglu, N. (2007). The environment and its impact on satisfaction with supplier performance: An investigation of the mediating effects of control mechanisms from the perspective of the manufacturer in the USA. Industrial Marketing Management, 36(4), 458-469. https://doi.org/10.1016/j.indmarman.2005.12.006

Salomann, H., Kolbe, L., \& Brenner, W. (2005). Self-services in customer relationships: balancing high-tech and high-touch today and tomorrow. E-service Journal, 4(2), 65-84. https://doi.org/10.1353/esj.2006.0011

Schemer, A., Wünderlich, N. V., \& Von Wangenheim, F. (2015). The Value of Self-Service: Long-Term Effects of Technology-Based Self-Service Usage on Customer Retention. MIS Quarterly, (39: 1) 177-200. Retrieved from https://aisel.aisnet.org/misq/vol39/iss1/11/

Shih, Y. Y., \& Fang, K. (2004). The use of a decomposed theory of planned behavior to study Internet banking in Taiwan. Internet Research, 14(3), 213-223. https://doi.org/10.1108/10662240410542643 
Simon, F., \& Usunier, J. C. (2007). Cognitive, demographic, and situational determinants of service customer preference for personnel-in-contact over self-service technology. International Journal of Research in Marketing, 24(2), 163-173. https://doi.org/10.1016/j.ijresmar.2006.11.004

Thomas, J. S. (2001). A methodology for linking customer acquisition to customer retention. Journal of Marketing Research, 38(2), 262-268. https://doi.org/10.1509/jmkr.38.2.262.18848

Van Akkeren, J., \& Cavaye, A. L. (1999), Factors affecting entry-level internet technology adoption by small business in Australia: An empirical study. In Proceedings of the 10th Australasian Conference on Information Systems. Retrieved from https://pdfs.semanticscholar.org/65ed/fb9bc75e35c7a94315785a5c04e04683eea5.pdf

Venkatesh, V., \& Davis, F.D. (2000). A theoretical extension of the technology acceptance model: Four longitudinal field studies. Management Science, 46(2), 186-204. https://doi.org/10.1287/mnsc.46.2.186.11926

Verhoef, P. C. (2003). Understanding the effect of customer relationship management efforts on customer retention and customer share development. Journal of Marketing, 67(4), 30-45. https://doi.org/10.1509/jmkg.67.4.30.18685

Weijters, B., Rangarajan, D., Falk, T., \& Schillewaert, N. (2007). Determinants and outcomes of customers' use of self-service technology in a retail setting. Journal of Service Research, 10(1), 3-21. https://doi.org/10.1177/1094670507302990

Williams, M. D., Slade, E. L., \& Dwivedi, Y. K. (2014). Consumers' Intentions to Use E-Readers. Journal of Computer Information Systems, 54(2), 66-76. https://doi.org/10.1177/1461444811410407

Wilson, D. T. (1995). An integrated model of buyer-seller relationships. Journal of the Academy of Marketing Science, 23(4), 335-345. Retrieved from https://pdfs.semanticscholar.org/e106/719db7bcfcdd95248d84fae311e95f43107e.pdf

Yu, C. S. (2012). Factors affecting individuals to adopt mobile banking: Empirical evidence from the UTAUT model. Journal of Electronic Commerce Research, 13(2), 104. Retrieved from http://www.jecr.org/sites/default/files/13_3_p01_0.pdf

Zeithaml, V. A., Berry, L. L. \& Parasuraman, A. (1996). The behavioral consequences of service quality. Journal of Marketing, 60(2) 31-46. Retrieved from http://www.jstor.org/stable/1251929

Zhou, T., Lu, Y., \& Wang, B. (2010). Integrating TTF and UTAUT to explain mobile banking user adoption. Computers in Human Behavior, 26(4), 760-767. https://doi.org/10.1016/j.cihb.2010.03.024

Zhu, Y. Q., \& Chen, H.G. (2012). Service fairness and customer satisfaction in Internet banking: exploring the mediating effects of trust and customer value. Internet Research, 22(4), 
482-498. https://doi.org/10.1108/10662241211251006

\section{Copyright}

Copyright for this article is retained by the author(s), with first publication rights granted to the journal.

This is an open-access article distributed under the terms and conditions of the Creative Commons Attribution license (http://creativecommons.org/licenses/by/4.0/). 